\title{
TREE MORTALITY IN MATURE RIPARIAN FOREST: IMPLICATIONS FOR FREMONT COTTONWOOD CONSERVATION IN THE AMERICAN SOUTHWEST
}

\author{
Douglas C. Andersen 1
}

\begin{abstract}
Mature tree mortality rates are poorly documented in desert riparian woodlands. I monitored deaths and calculated annual survivorship probability $\left(\mathrm{P}_{\mathrm{S}}\right)$ in 2 groups of large $(27-114 \mathrm{~cm} \mathrm{DBH})$, old ( $\geq 40$ years old) Fremont cottonwood (Populus fremontii Wats.) in a stand along the free-flowing Yampa River in semiarid northwestern Colorado. $\mathrm{P}_{\mathrm{S}}=0.993$ year-1 in a group $(n=126)$ monitored over 2003-2013, whereas $\mathrm{P}_{\mathrm{S}}=0.985$ year ${ }^{-1}$ in a group $(n=179)$ monitored over the same period plus 3 earlier years (2000-2003) that included drought and a defoliating insect outbreak. Assuming $\mathrm{P}_{\mathrm{S}}$ was the same for both groups during the 10 -year postdrought period, the data indicate that $\mathrm{P}_{\mathrm{S}}=0.958$ year ${ }^{-1}$ during the drought. I found no difference in canopy dieback level between male and female survivors. Mortality was equal among size classes, suggesting $P_{S}$ is independent of age, but published longevity data imply that either $\mathrm{P}_{\mathrm{S}}$ eventually declines with age or, as suggested in this study, periods with high $\mathrm{P}_{\mathrm{S}}$ are interrupted by episodes of increased mortality. Stochastic population models featuring episodes of low $\mathrm{P}_{\mathrm{S}}$ suggest a potential for an abrupt decline in mature tree numbers where recruitment is low. The modeling results have implications for woodland conservation, especially for relictual stands along regulated desert rivers.
\end{abstract}

RESUMEN.-La mortalidad de los árboles maduros en el desierto ribereño está pobremente documentada. Monitoreé las muertes y calculé la probabilidad de supervivencia anual $\left(\mathrm{P}_{\mathrm{S}}\right)$ en dos grupos de largo $(27-114 \mathrm{~cm}$ DAP), y de edad ( $\geq 40$ años) del álamo (Populus fremontii Wats.) en un grupo de árboles a lo largo del río Yampa en el noroeste semiárido de Colorado. Encontré $\mathrm{P}_{\mathrm{S}}=0.993$ año $^{-1}$ en el grupo $(n=126)$ monitoreado entre 2003-2013, mientras que $\mathrm{P}_{\mathrm{S}}=0.985$ año-1 en el grupo $(n$ = 179) monitoreado durante el mismo período, más de tres años anteriores (2000 a 2003) que incluyó la sequía y una plaga de insectos defoliadores. Asumiendo que la $\mathrm{P}_{\mathrm{S}}$ fue la misma para ambos grupos en el período de 10 años posterior a la sequía, los datos indican que la $\mathrm{P}_{\mathrm{S}}=0.958$ año $^{-1}$ durante la sequía. No encontré diferencias en el nivel de muerte regresiva del dosel entre machos y hembras sobrevivientes. La mortalidad fue igual entre clases de tamaño, lo que sugiere que la $\mathrm{P}_{\mathrm{S}}$ es independiente de la edad, pero los datos publicados sobre longevidad implican que $\mathrm{P}_{\mathrm{S}}$ disminuye eventualmente con la edad o, como se sugiere en este estudio, los períodos con alta $\mathrm{P}_{\mathrm{S}}$ son interrumpidos por episodios de aumento en la mortalidad. Los modelos estocásticos de poblaciones que muestran episodios de baja $\mathrm{P}_{\mathrm{S}}$ sugieren un potencial declive en el número de árboles maduros donde el reclutamiento es bajo. El modelaje de los resultados tiene implicaciones en la conservación de los bosques, especialmente en los grupos remanentes de árboles a lo largo de los ríos de los desiertos.

Riparian woodlands and forests are major components of naturally functioning riverine ecosystems in semiarid and arid regions (hereafter, drylands). The trees have a major role in determining the structure and dynamics of the physical environment, and their form and high productivity provide a unique array of resources to consumers (see Stromberg et al. 2012). In drylands within the Colorado River basin, which drains much of the southwestern United States, the dominant riparian tree is often Fremont cottonwood (Populus fremontii subsp. fremontii S. Watson and Populus deltoides subsp. wislizenii (S. Watson) Eckenwalder, as well as their intergrades (taxonomy follows Eckenwalder 1977). This dioecious, phreatophytic species reproduces primarily sexually, and cohorts interact with the physical environment in a manner that results in a patchwork of variously aged trees. These patches, together with the disturbance necessary to generate sites for seedling recruitment, can form a quasi-stable forest through equilibrium patch dynamics (Scott 2013). The dynamics of individual forest patches are controlled primarily by the processes of seedling recruitment (Cooper et al. 1999), sapling survivorship and growth (Andersen 2005), and mature tree mortality.

Mortality rates in patches containing mature trees are poorly understood, in part because of the long time frames needed to obtain reliable estimates. Large, old trees are of great ecological value because they can be critical pollen and seed sources and because their physiognomy and other attributes provide

${ }^{1}$ U.S. Geological Survey, Fort Collins Science Center, Fort Collins, CO. E-mail: doug_andersen@usgs.gov 


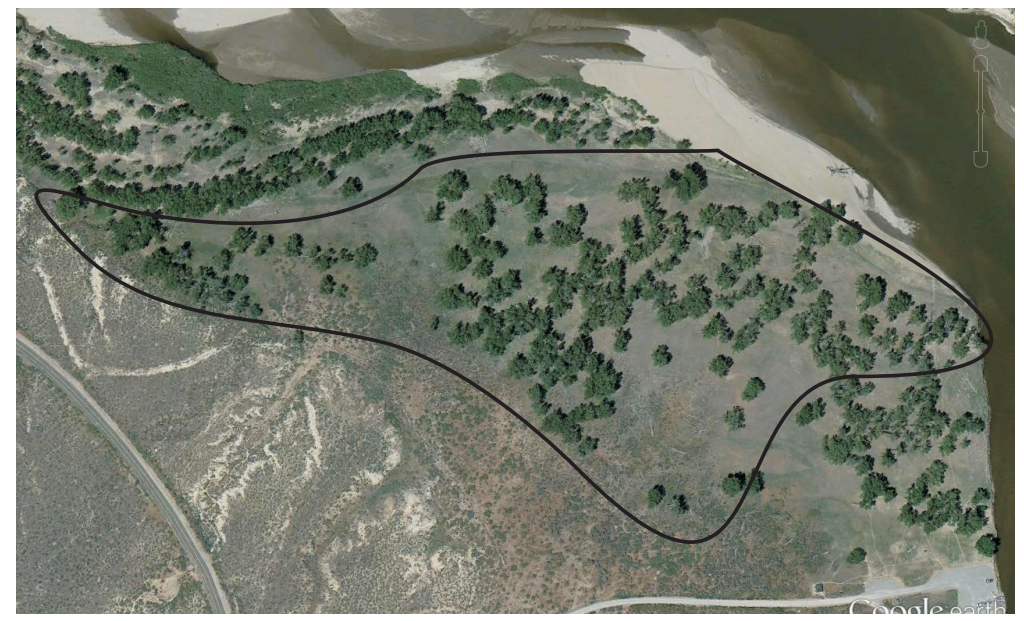

Fig. 1. Google Earth image (imagery date 20 June 2013) of Deerlodge Park on the Yampa River with the population of mapped old-growth trees outlined. North is to the top of the image, and the river flows from east to west. The Deerlodge Park public campground area includes the unmapped trees closest to the river access point and parking area at the bottom right of the image. Trees immediately north of the mapped stand are relatively young. The width of the mapped area in the image is approximately $650 \mathrm{~m}$.

unique food, shelter, and other resources to numerous wildlife species, some of which are obligately riparian (Hammond et al. 2001, Sabo et al. 2005, Brand et al. 2008, Smith and Finch 2014). Mature trees have especially high ecological value along rivers where natural recruitment into the mature age class is severely hindered (e.g., by anthropogenic alteration of stream hydrology and fluvial geomorphic processes; Merritt and Cooper 2000). Tree deaths in such "relictual" populations initiate a successional process that replaces forest and its associated fauna with dryland herbaceous vegetation and shrubs already present in adjacent uplands (Merritt and Cooper 2000), leading to a net loss of species and a decline in local and regional biodiversity (Brand et al. 2011, Wallace et al. 2013). Besides contributing to our basic understanding of cottonwood ecology, knowledge of mature cottonwood mortality rates can provide insight into the level of urgency needed in undertaking management action to prevent such biodiversity losses.

Here I document mortality over a 13-year period in a stand of old-growth Fremont cottonwood in a naturally functioning desert riverine ecosystem. I assess whether senescence is present (i.e, whether mortality increases with age) by testing the null hypothesis that mortality is independent of tree size, a surrogate for tree age. I also assess whether male and female trees surviving through the monitoring period differ in their level of stressinduced canopy loss. I use the demographic data to model dynamics in old-growth Fremont cottonwood stands. The data and modeling results have implications for forest conservation and management along rivers in the Upper Colorado River basin and elsewhere.

\section{Methods}

I monitored Fremont cottonwood trees growing on the Yampa River floodplain in semiarid northwestern Colorado. The study area was an approximately 6.5-ha portion of Deerlodge Park (DLP; elevation approximately $1705 \mathrm{~m}$ ) within Dinosaur National Monument $\left(40.4484^{\circ} \mathrm{N}\right.$, $\left.108.5150^{\circ} \mathrm{W}\right)$ that contained only large trees $(\geq 27 \mathrm{~cm}$ diameter at breast height $[1.3 \mathrm{~m}$ $\mathrm{DBH}])$. The only tree of large stature at DLP is Fremont cottonwood, with a few individuals $>200$ years old (D.J. Cooper unpublished data). Precise ages of monitored trees are unknown, but the trees likely belong to cohorts established in 1929, 1947, and 1952 (Cooper et al. 2003), making them "middle-aged" relative to potential Fremont cottonwood longevity (see Discussion). The monitored stand (Fig. 1) was representative of similarly mature but less accessible stands elsewhere in the DLP area. 
TABLE 1. Dates of tree surveys, number of trees assessed, and calculated annual survivorship $\left(\mathrm{P}_{\mathrm{S}}\right)$. Tree groups la and $1 \mathrm{~b}$ were pooled and the date of 15 April 2000 used to calculate the length of the monitoring period. Status for all trees was reassessed on 18 June 2013.

\begin{tabular}{|c|c|c|c|c|c|c|}
\hline Tree group & Survey date & $\begin{array}{l}\text { Number of } \\
\text { live trees } \\
\text { mapped }\end{array}$ & $\begin{array}{l}\text { Number of } \\
\text { trees dying } \\
\text { prior to } \\
\text { reassessment }\end{array}$ & $\begin{array}{c}\text { Time } \\
\text { interval } \\
\text { (years) }\end{array}$ & $\begin{array}{l}\text { Proportion } \\
\text { dying during } \\
\text { the time } \\
\text { interval (m) }\end{array}$ & $\mathrm{P}_{\mathrm{S}}\left(\right.$ year $\left.^{-1}\right)$ \\
\hline la & 27 March 2000 & 65 & 7 & & & \\
\hline $1 b$ & 4 May 2000 & 63 & 18 & & & \\
\hline Pooled 1 & (15 April 2000) & $(128)$ & $(25)$ & 13.18 & 0.1953 & 0.9836 \\
\hline 2 & 6 August 2003 & 94 & 3 & 9.87 & 0.0319 & 0.9967 \\
\hline 3 & 25 March 2004 & 82 & 5 & 9.24 & 0.0610 & 0.9932 \\
\hline \multicolumn{2}{|c|}{ Mean of groups 2 and 3} & & & 9.55 & & 0.9950 \\
\hline \multicolumn{2}{|c|}{ TOTAL } & 304 & & & & \\
\hline
\end{tabular}

I mapped the location of all live and dead trees within the study area using a total station in a series of surveys that produced 4 tree groups differentiated by survey date, which spanned from 2000 to 2004 (Table 1). Each bole distinct at ground level was considered a unique tree. About $5 \%$ of trees split into 2 or more boles of nearly equal size $1-2 \mathrm{~m}$ above ground level, but I considered these complexes a single tree. The status (living or dead) of each tree was noted at the time of mapping. The initial DBH of each live tree was measured in either October 2002 (for tree groups first mapped in 2000) or when the group was mapped. I reassessed the status of each mapped tree on 17-19 June 2013. For each live tree, I remeasured DBH, used flower structure to assign sex, and visually estimated the proportion of the tree's canopy that was dead.

An irruption of defoliating cottonwood leaf beetles (Chrysomela scripta F.) was underway when monitoring began in 2000. Beetles first became apparent at DLP in 1997 and possibly peaked in abundance in 2001, but herbivory levels in mature trees is unknown (Andersen and Nelson 2002, Andersen 2005). Beetle abundance dropped precipitously during summer 2002, and none were evident in subsequent growing seasons.

The Yampa River has a nearly natural flow regime that features a spring flood driven by snowmelt in the Rocky Mountain headwaters. Mean annual discharge at DLP is approximately $55 \mathrm{~m}^{3} \cdot \mathrm{s}^{-1}$ and the mean peak flood discharge is approximately $400 \mathrm{~m}^{3} \cdot \mathrm{s}^{-1}$ (Merritt and Cooper 2000). The study period (2000-2013) included a regional drought that began in the late 1990s and culminated in 2002, one of the driest years in the Yampa River basin in the last 1000 years (Gray et al.
2011). The record low 2002 flood was followed by unusually high discharges in 2008 and 2011 (Fig. 2). Details concerning floodplain vegetation can be found in Merritt and Cooper (2000) and Uowolo et al. (2005). Details concerning climate and soils are available in Cooper et al. (1999), Adair et al. (2004), and Williams and Cooper (2005).

Annual survivorship probabilities $\left(\mathrm{P}_{\mathrm{S}}\right)$ from mortality rates $(\mathrm{m})$ calculated as the proportion of trees alive at the start of the monitoring period that died during that period was estimated using the formula

$$
\mathrm{P}_{\mathrm{S}}=(1-\mathrm{m})^{(1 / \mathrm{t})},
$$

(Eq. 1)

where $t$ is the length of the monitoring period in years. Because the monitoring periods for the 2 groups overlapped in the postdrought period, I estimated survivorship during the drought by assuming that all trees were exposed to the same postdrought $\mathrm{P}_{\mathrm{S}}$ value and solving the equation

$\left(\mathrm{N} \times \mathrm{m}_{1}\right)+\left\{\left[\mathrm{N}-\left(\mathrm{N} \times \mathrm{m}_{1}\right)\right] \times \mathrm{m}_{2}\right\}=\mathrm{D}$,

(Eq. 2)

where $\mathrm{N}$ is the number of live trees first monitored in $2000, \mathrm{~m}_{1}$ is the mortality during the drought period, $\mathrm{m}_{2}$ is the mortality during the post-drought period, and D is the total number from the original $\mathrm{N}$ trees that died during the 2000-2013 period.

I tested 2 hypotheses concerning factors affecting mortality in the stand. First, I tested the hypothesis that mortality was independent of DBH, a surrogate for age (Hinchman and Birkeland 1995), in order to assess whether Fremont cottonwood populations display senescence (i.e., an annual mortality rate that increases with age). I divided trees measured in 


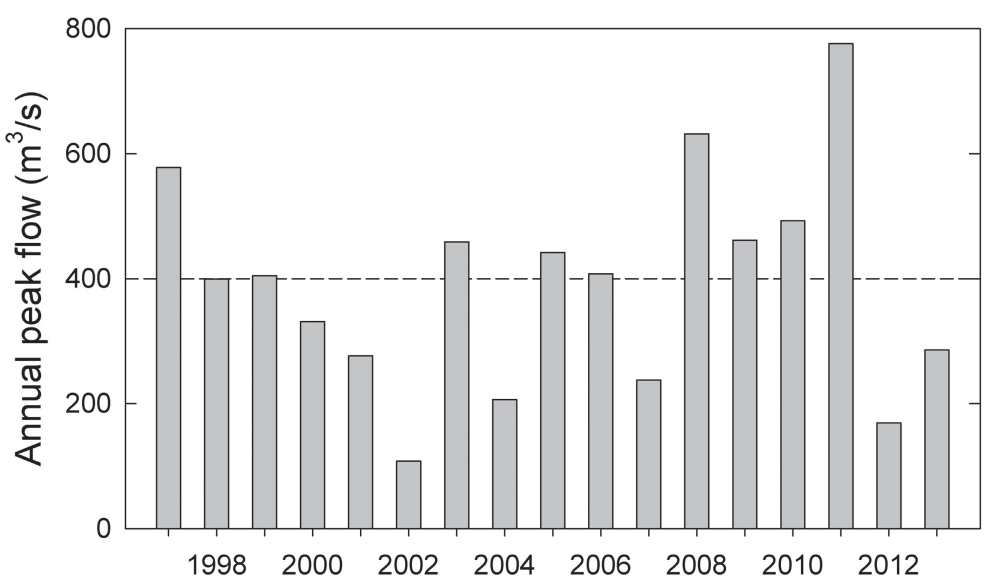

Fig. 2. Yampa River annual instantaneous peak flow measured at Deerlodge Park, Dinosaur National Monument, Colorado (USGS Gage 09260050). The dashed line is the mean peak for the period 1982-2013 ( $n=30$ years). Tree monitoring began in 2000 and ended in 2013.

2003 or 2004 into 3 size classes-small $(<50$ $\mathrm{cm})$, medium ( $\geq 50$ but $<70 \mathrm{~cm}$ ), and large $(\geq 70 \mathrm{~cm})$-and used Pearson's chi-square test of independence to assess whether the proportion surviving differed among the classes.

Secondly, I tested the hypothesis that drought is more stressful to female trees than to male trees, a pattern noted in other studies (Hultine et al. 2007, Rood et al. 2013). Because I determined tree sex at the end of the study, I could not compute sex-specific $\mathrm{P}_{\mathrm{S}}$ values. Rather, I used the chi-square test of independence to assess whether the evidence of past stress (canopy branch dieback) differed between male and female trees alive at the end of the study. I also used ANCOVA to test whether the relationship between initial size $(\mathrm{DBH})$ and radial growth of trees surviving over 2003-2013 differed between males and females. Linear regressions were performed in SigmaPlot 11. All other statistical tests were performed using SYSTAT 11.

I used mortality data from the DLP population to model persistence of a relictual Fremont cottonwood patch undergoing successional conversion to non-forest. I ignored the possibility of acute, catastrophic stand destruction and modeled tree survival as a stochastic process, assuming that (1) each tree in a population lives or dies independently of all other trees (i.e., mortality is not spatially contagious), (2) the probability of survival through a year $\left(\mathrm{P}_{\mathrm{S}}\right)$ is equal for all trees in the population, and (3) the fate of each tree is a random process.

I added random environmental variation (environmental stochasticity) to the survivorship probability in 2 ways. First, I randomly interrupted "background" or "normal" high annual survivorship $\left(\mathrm{P}_{\mathrm{SH}}\right)$ with an episode of low survivorship $\left(\mathrm{P}_{\mathrm{SL}}\right)$, as might be brought about by drought or other major environmental stress. Each year, the probability that $\mathrm{P}_{\mathrm{S}}=\mathrm{P}_{\mathrm{SL}}$ was a constant value, $\mathrm{P}_{\mathrm{BAD}}$, but $\mathrm{I}$ varied the value of $\mathrm{P}_{\mathrm{BAD}}$ in independent trials from (on average) one unfavorable year during each 10 -year interval $\left(\mathrm{P}_{\mathrm{BAD}}=0.10\right)$ to one unfavorable year each 6.67 years $\left(\mathrm{P}_{\mathrm{BAD}}=0.15\right)$. Second, $\mathrm{I}$ assumed that $\mathrm{P}_{\mathrm{SH}}$ and $\mathrm{P}_{\mathrm{SL}}$ were random variables with an assigned mean value and a standard deviation (SD) equal to $1.0 \%$ and $3.0 \%$ of the mean, respectively. I made SD larger for $\mathrm{P}_{\mathrm{SL}}$ because I judged the variety and intensity of unfavorable conditions to be larger than the set of environmental conditions that produce favorable conditions. In separate trials, I doubled the SD values to determine the effect of greater environmental variation. Regardless of $\mathrm{SD}$ values, the final $\mathrm{P}_{\mathrm{SL}}$ value, if applied to the population, could equal but not exceed that year's (random) value for $\mathrm{P}_{\mathrm{SH}}$. Given the mean $\mathrm{P}_{\mathrm{SH}}$ and $\mathrm{P}_{\mathrm{SL}}$ values and their respective $\mathrm{SD}$ values, I used the Excel function NORM.INV (incorporating a random number from a uniform distribution between 0 and 1) to generate random values of $\mathrm{P}_{\mathrm{SH}}$ and $\mathrm{P}_{\mathrm{SL}}$. Finally, I added 
TABLE 2. Fremont cottonwood survivorship in 3 size classes over the interval 2003/04 to 2013. Size class assignment is based on DBH at the time the tree was mapped in 2003 (Tree group 2) or 2004 (Tree group 3): small $(<50 \mathrm{~cm}$ ); medium $(\geq 50$ but $<70 \mathrm{~cm})$, and large $(\geq 70 \mathrm{~cm})$. The $\chi^{2}$ statistic was used to test the null hypothesis that the proportion surviving is equal across size classes. Degrees of freedom $=2$ in all cases.

\begin{tabular}{llccccc}
\hline Tree group & Size class & $\begin{array}{c}\text { Number of } \\
\text { trees at start }\end{array}$ & $\begin{array}{c}\text { Number } \\
\text { surviving }\end{array}$ & $\begin{array}{c}\text { Percent } \\
\text { surviving }\end{array}$ & Statistic & $P$ \\
\hline 2 & Small & 32 & 30 & 93.8 & 2.59 & 0.27 \\
& Medium & 42 & 42 & 100 & & \\
3 & Large & 19 & 18 & 94.7 & & 0.35 \\
& Small & 27 & 26 & 96.3 & 2.08 & \\
\multirow{5}{*}{ Pooled } & Medium & 49 & 42 & 85.7 & & 0.82 \\
& Large & 10 & 9 & 90.0 & & \\
& Small & 59 & 56 & 94.9 & & \\
& Medium & 91 & 84 & 92.3 & & \\
\hline
\end{tabular}

demographic stochasticity by using the binomial distribution to deal with an entire initial population $\left(\mathrm{N}_{0}\right)$ of 1000 trees in one simulation run, and repeating the process 125 times to generate a mean number of trees surviving, as well as the variance associated with the mean and the maximum and minimum numbers of survivors for the set of 125 replicate determinations. Given the number of live trees remaining in year $i\left(\mathrm{~N}_{i}\right)$ and the individual probability of survival through the year $\left(\mathrm{P}_{\mathrm{S}}\right)$ determined as outlined above, I used the Excel function BINOM.INV (with the addition of a criterion value $[\alpha]$ generated as a uniform random number between 0 and 1 ) to return the number of surviving trees that correspond to the value $\alpha$ in the cumulative distribution of the binomial distribution. Details are provided in the Appendix.

\section{RESUlTS}

Annual survivorship probability $\left(\mathrm{P}_{\mathrm{S}}\right)$ for the full 13-year period 2000-2013 $\left(\mathrm{P}_{\mathrm{S}}=0.984\right.$ year $^{-1}$ ) was lower than the value obtained for the groups (Tree groups 2 and 3) monitored in the postdrought (2003/04-2013) period $\left(\mathrm{P}_{\mathrm{S}}=\right.$ 0.997 and 0.993 year $^{-1}$ ) (Table 1). Substituting the mean $\mathrm{P}_{\mathrm{S}}$ value for the postdrought period $(0.9950)$ and the mean length of the postdrought monitoring periods (9.55 years) into Eq. 2 produces an estimate of survivorship during the drought period of $\mathrm{P}_{\mathrm{S}}=0.9545$ year $^{-1}$. Although Fremont cottonwood is capable of producing stem and root sprouts under some conditions (e.g., Stromberg and Rychener 2010), I saw no evidence of sprout production in any tree in the monitored stand, supporting my assumption that my tally of dead trees was accurate.
The test for independence between mortality rate and tree size indicated no significant difference in the proportion of each size class that survived through the postdrought period (Table 2). Nor did I detect any gender difference in the frequency distribution of 2013 canopy condition classes (Fig. $3 ; \chi^{2}=6.42$, df $=8, P=0.60)$, or in the relationships between initial size and radial growth (Fig. 4, Table 3).

Figure 5 shows the rate of decline in a population of 1000 trees experiencing constant $\mathrm{P}_{\mathrm{S}}$ at each of the drought and postdrought DLP rates. Figure 5 also depicts the results of the stochastic models in which the postdrought rate is randomly interrupted by the drought rate. In the case of $\mathrm{P}_{\mathrm{SL}}$ operating, on average, 1 year in $6.7\left(\mathrm{P}_{\mathrm{BAD}}=0.15\right)$, the model with lowest SD values indicates that, on average, $66 \%$ of the initial population dies within about 85 years (Fig. 5A). However, some of the simulations had that level of population loss within 60 years. Increasing the variance of $\mathrm{P}_{\mathrm{SH}}$ and $\mathrm{P}_{\mathrm{SL}}$ shifted the curve to the left (Fig. 5B), with mean time to loss of $66 \%$ of the population declining to about 60 years and the most rapid declines taking only about 40 years. Reducing the frequency of "bad" years by $33 \%\left(\mathrm{P}_{\mathrm{BAD}}=\right.$ $0.10)$ shifts the curve to the right (Fig. $5 \mathrm{~B})$, but the mean time for loss of $66 \%$ of the population is increased by only a decade. In all the stochastic simulations, some trees remained alive after 300 years, suggesting that at least one of the model parameters is conservative.

\section{Discussion}

There are very few estimates of mortality rates in mature Fremont cottonwood trees in a 


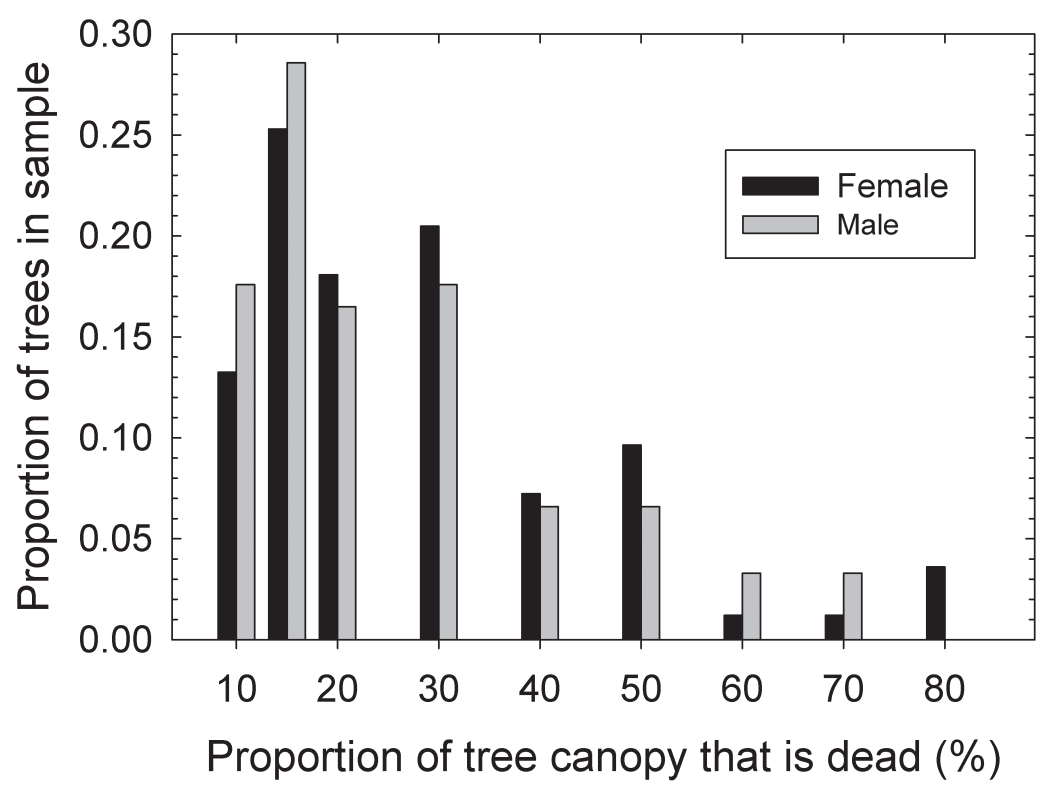

Fig. 3. Distributions for the percentage $(\%)$ of the canopy that was dead in individual live Fremont cottonwoods at the June 2013 census. The distributions for male $(n=91)$ and female $(n=83)$ trees are not significantly different $\left(\chi^{2}=\right.$ $6.42, \mathrm{df}=8, P=0.60$ ).

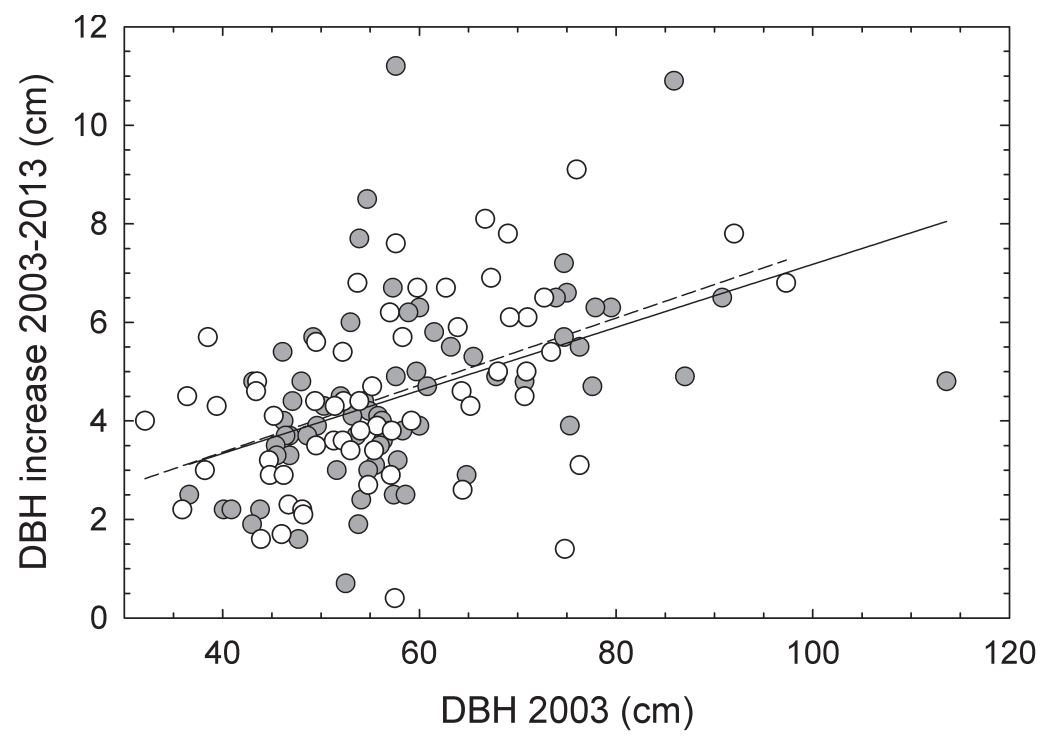

Fig. 4. Size-related radial growth of male (filled circles, solid line) and female (open circles, dashed line) Fremont cottonwood trees at DLP during the period 2003-2013. The 2 regression lines are not significantly different (see Table 3). The linear regression for the pooled data (not shown) is $y=0.735+(0.0655 x)$, where $y$ and $x$ are in centimeters $(n=131$, $\left.r^{2}=0.22, P<0.001\right)$.

natural, unstressed setting. Scott et al. (1999) and Scott et al. (2000) monitored survivorship in unstressed populations for short periods (2-4 years) and reported $\mathrm{P}_{\mathrm{S}}$ values (or provided the data to calculate values) that ranged from 0.97 to 1.00 year $^{-1}$. Rowland and Johnson (2001) monitored mortality in 6 stands of 30-40-yearold Fremont cottonwood along a stress gradient 


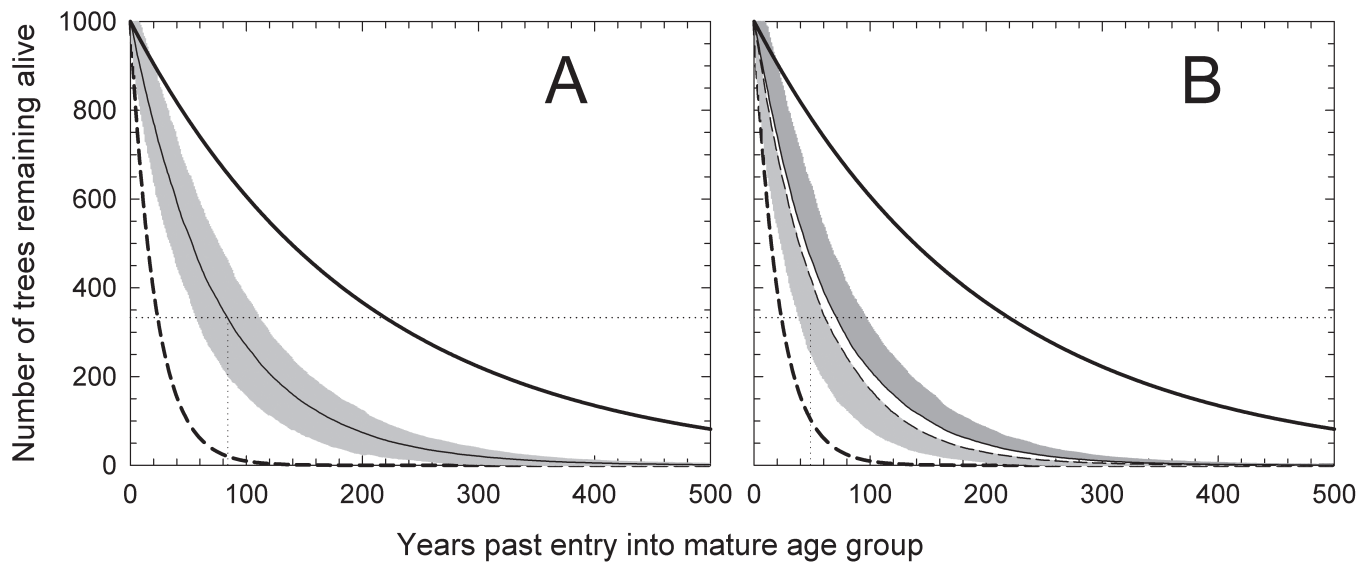

Fig. 5. Models of decline in a population of 1000 mature trees using $\mathrm{P}_{\mathrm{S}}$ values documented in this study.

A, The heavy lines are the deterministic models for a constant high survivorship (solid line, $\mathrm{P}_{\mathrm{SH}}=0.995$ year-1) and constant low survivorship (dashed line, $\mathrm{P}_{\mathrm{SL}}=0.9545$ year-1). The thin solid line depicts the mean number of trees remaining at each year from 125 runs of a stochastic model in which (1) $\mathrm{P}_{\mathrm{SH}}$ becomes a random variable with mean 0.995 and $\mathrm{SD}=1 \%$ of the mean, (2) $\mathrm{P}_{\mathrm{SL}}$ becomes a random variable with mean 0.9545 and $\mathrm{SD}=3 \%$ of the mean, and (3) $\mathrm{P}_{\mathrm{SL}}$ occurs randomly with probability equals 0.15 in any given year (i.e., on average in 1 out of 6.6 years). The gray area encompasses 2 standard deviations above and below the mean. Dotted lines indicate that on average, $66 \%$ of the population is lost after approximately 85 years.

B, The same outer curves (heavy lines) as in panel A. Inner curve to the left (thin dashed line) is a stochastic model as in panel $\mathrm{A}$, but with $\mathrm{SD}$ values for $\mathrm{P}_{\mathrm{SH}}$ and $\mathrm{P}_{\mathrm{SL}}$ doubled to $2 \%$ and $6 \%$, respectively. The light gray area encompasses 2 standard deviations below the mean, and the dotted line indicates that, on average, $66 \%$ of the population is lost after approximately 60 years. Inner curve to the right is the same model as to the left but with probability of $\mathrm{P}_{\mathrm{SL}}$ occurring in any year reduced from 0.15 to 0.10 (i.e., on average 1 year in 10). The dark gray area encompasses 2 standard deviations above the mean.

TABLE 3. Results of analysis of covariance (ANCOVA) assessing the effect of sex on the relationship between initial size (DBH in 2003) and radial growth over the 2003-2013 period in mature Fremont cottonwood.

\begin{tabular}{lcrrrr}
\hline Source & Sum of squares & df & Mean square & $F$ ratio & $P$ \\
\hline Sex & 10.673 & 1 & 10.673 & 2.531 & 0.114 \\
Covariate (DBH in 2003) & 120.027 & 1 & 120.027 & 28.464 & $<0.001$ \\
Error & 552.406 & 131 & 4.217 & & \\
\hline
\end{tabular}

produced by salinization and depth to ground water. $\mathrm{P}_{\mathrm{S}}$ values calculated from their data for 2 sequential years ranged from 0.955 to 1.00 year $^{-1}$ in the first year, and from 0.908 to 0.977 year $^{-1}$ along the gradient in the second year.

Cottonwoods and poplars (Populus sp.) are considered to be fast-growing but relatively short-lived trees. The shorter lifespan is presumably a trade-off for life history traits promoting rapid resource acquisition and the allocation of materials to growth and reproduction rather than defense against herbivores, pathogens, or mechanical injury (e.g., from wind). Maximum longevity of cottonwoods was generally presumed to be $<150$ years, although some individuals attained ages of 200+ years (Rood and Polzin 2003). Rood and Polzin (2003) suggested that Populus species in the taxonomic section Aigeiros, including Fremont cottonwood, die before reaching age 200, whereas those in section Tacamahaca can reach age 400. However, recent work has indicated that members of the Aigeiros section can attain ages $>350$ years in some locations (Edmondson et al. 2014). Nevertheless, a constant $\mathrm{P}_{\mathrm{S}}$ as high as observed at DLP leads to trees older than any Populus observed in nature (Fig. 5). Several scenarios can account for the observed $\mathrm{P}_{\mathrm{S}}$ value while producing a more realistic maximum lifespan. First, 2003-2013 may have been an exceptionally favorable period, leading to $\mathrm{P}_{\mathrm{S}}$ being unusually high. Alternatively, the observed $\mathrm{P}_{\mathrm{S}}$ 
may constitute a normal or "background" survivorship rate that is periodically interrupted by episodes of unfavorable conditions in which $\mathrm{P}_{\mathrm{S}}$ declines to rates at or below the $\mathrm{P}_{\mathrm{S}}$ of 0.9545 year $^{-1}$ estimated for the period when both defoliation and drought were present. A third scenario is that senescence is present in Fremont cottonwood populations; however, I failed to detected it in the monitored stand because trees were too young, sample sizes were too small, or my assumption of a tight size-age relationship was invalid.

Episodes of high mortality among mature Fremont cottonwoods can arise from disturbances such as fire (Stromberg and Rychener 2010), extreme drought, or floods. Variability in disturbance type and intensity, coupled with local site conditions and genotypic and phenotypic variation among trees would likely lead to differential effects among both cohorts and populations. For example, Gitlin et al. (2006) examined mortality among 30 Fremont cottonwoods in each of 20 stands across a portion of Arizona affected by the same drought noted in this study and reported that the proportion of trees dying ranged from $0 \%$ to $97 \%$. Stromberg et al. (1993) reported $100 \%$ survivorship of mature trees (stems $>10-\mathrm{cm}$ diameter) through a 1-in-10-year flood, whereas a 1-in-25-year flood caused mortality (as evidenced by patch size reductions) in all cohorts present (Stromberg et al. 1997). Lytle and Merritt (2004) developed a model of Fremont cottonwood population dynamics and assigned mature cottonwoods the equivalent of $\mathrm{P}_{\mathrm{S}}=$ 0.97 year $^{-1}$ during years when there was neither drought nor flood mortality. In a drought year, the $\mathrm{P}_{\mathrm{S}}$ decreased to 0.9603 year $^{-1}$, whereas in a flood year it decreased to 0.9506 year ${ }^{-1}$. The source(s) for their $\mathrm{P}_{\mathrm{S}}$ values is not made clear. Drought or insect herbivory, acting either alone or in combination, could have stressed the DLP cottonwoods. Whether the large 2008 or 2011 floods were detrimental is unclear. The precise time or cause of death is not known for any monitored tree.

Senescence does not appear to be present in all tree species and may be absent in Fremont cottonwood. After reviewing tree mortality patterns, Harcombe (1987) concluded that rates in mature trees, which he defined as corresponding to sizes $>15$ or $20 \mathrm{~cm} \mathrm{DBH,}$ were generally either constant until the largest (oldest) classes, whereupon the mortality rate rose, signaling the presence of senescence, or the rates were constant across age classes. $\mathrm{P}_{\mathrm{S}}$ values calculated from his data range from 0.980 to 0.995 year $^{-1}$. Busing (2005) found a decline in survivorship in the largest size class in only 2 of the 3 most abundant tree species in old growth Appalachian cove forest. He reported $\mathrm{P}_{\mathrm{S}}$ values ranging from 0.995 to 0.986 year $^{-1}$. Richardson et al. (2009) examined large individuals $(\geq 30 \mathrm{~cm} \mathrm{DBH})$ of 6 species of New Zealand trees over a 42 -year period and detected a size effect in only half of the species.

If senescence is present in Fremont cottonwood, it may become apparent only in older trees and under special circumstances. Peterken (1996) noted the episodic nature of mortality in old-growth forests. Ozolincius et al. (2005) reported that survivorship rates in several European north-temperate forest species, including Populus tremula, declined from approximately 0.995 year $^{-1}$ in trees $<80$ years old to $0.97-0.98$ year $^{-1}$ in older trees. Most dead trees had symptoms of wind damage, and stem insects and root diseases were identified as mortality causes for $14 \%$ and $17 \%$ of dead trees, respectively. The mortality rate increased by a factor of 10 when extreme weather conditions (wind or drought) or insect outbreaks occurred. Similarly, Csilléry et al. (2013) noted that rare episodes of high annual mortality $\left(\mathrm{P}_{\mathrm{S}}<0.950\right.$ year $\left.^{-1}\right)$ punctuated sequences of years with low or very low annual mortality rates in montane coniferous forests. In general, age can increase the likelihood of successful attack by wood-decaying fungi, which can weaken a tree's structural integrity and predispose it to mortal injury (Schwarze et al. 2000).

Dryland riparian cottonwoods survive through growing seasons with severely restricted water availability by sacrificing branches (Rood et al. 2000), an adaptation that may allow individuals to attain relatively great age (i.e., 200-300 years as noted above). Further, individual cottonwood response to some disturbances (e.g., abrupt, sustained water-table decline) may be strongly dependent on antecedent conditions (e.g., the effect of water availability in prior years on root architecture; Scott et al. 2000, Shafroth et al. 2000, Andersen 2005). The concentration of the greatest radial growth in the largest and presumably oldest trees at DLP (Fig. 4) suggests 
that those trees were physiologically least affected by the insect irruption and drought. Stromberg and Patten (1992) found evidence suggesting that chronic water stress predisposed mature streamside black cottonwood (Populus trichocarpa) to death by either drought or flood. They noted that affected trees showed several years of poor growth before dying.

\section{Applying DLP Survivorship Rates to Relictual Cottonwood Stands in the Upper Colorado River Basin}

Andersen et al. (2007) mapped approximately 60,000 ha of dryland floodplain in the Upper Colorado River Basin (UCRB) and classified about one-third of the area as Fremont cottonwood forest with $\leq 5 \%$ canopy covera . The low canopy cover values suggest that those stands consist of cohorts recruited in the pre-dam era, with individuals at least as old as the trees monitored in this study. Given that the great majority of rivers and streams examined by Andersen et al. (2007) were regulated, many of the stands with low cover may be on relictual floodplains where natural recruitment processes are now absent. The stochastic modeling exercise (Fig. 5) suggests that most trees in such stands could die within the next 60 years. Although my models are simple and lack, for example, serial correlation in environmental variation that could accelerate losses (Beissinger 1995), this rate of loss is similar to that envisioned by Dixon et al. (2012) for relictual stands along the Missouri River. Using the time frame of 100 years for complete loss of existing relictual stands, replacement of the mapped UCRB forests would require planting $>200$ ha (494 acres) per year. However, Andersen et al. (2007) examined only a fraction of UCRB floodplains where Fremont cottonwood may be present. Thus, the forest area fated to disappear may be substantially $>20,000$ ha.

This study provides data and insight for use in assessing the survivorship pattern in populations of mature Fremont cottonwood trees, but whether the $\mathrm{P}_{\mathrm{S}}$ values documented here or the pattern of a high background $\mathrm{P}_{\mathrm{S}}$ periodically interrupted with episodes of low $\mathrm{P}_{\mathrm{S}}$ are applicable to trees on relictual floodplains is unclear. Because of the flood pulse reduction on relictual floodplains, trees there may have less access to water and nutrients, and be more vulnerable to stress. Nevertheless, assuming that current environmental conditions affecting mature trees are no worse on relictual floodplains than on naturally functioning floodplains, stochastic models suggest there is a potential for a rapid decline in tree numbers and possibly disappearance of whole stands in the coming decades. To obtain a better understanding of Fremont cottonwood longevity, comparative studies of mortality in mature cottonwood stands, the temporal and spatial variability of mortality, and the association of mortality with size and age are needed in both naturally functioning and relictual stands. The establishment of permanent plots in multiple stands of mature trees along both regulated and unregulated rivers, within which tree mortality is monitored annually, could provide the information needed to better understand the urgency needed to plan for or prevent a sharp decline in Fremont cottonwood forest area.

\section{ACKNOWLEDGMENTS}

I thank Mark Nelson, Rick Wydoski, and Marshall Wolfe for help in the field, and the staff of Dinosaur National Monument for permission to conduct this research. Tammy Fancher and Greg Auble provided help with survey data, and Greg Auble and other reviewers provided valuable comments on the manuscript. Financial support was provided by the U.S. Geological Survey and the Bureau of Reclamation. Any use of trade, product, or firm names is for descriptive purposes only and does not imply endorsement by the U.S. Government.

\section{Literature Cited}

Adair, E.C., D. Binkley, and D.C. Andersen. 2004. Patterns of nitrogen accumulation and cycling in riparian floodplain ecosystems along the Green and Yampa rivers. Oecologia 139:108-116.

Andersen, D.C. 2005. Characterizing flow regimes for floodplain forest conservation: an assessment of factors affecting sapling growth and survivorship on three cold desert rivers. Canadian Journal of Forest Research 35:2886-2899.

Andersen, D.C., D.J. Cooper, and K. Northcott. 2007. Dams, floodplain land use, and riparian forest conservation in the semiarid Upper Colorado River basin, USA. Environmental Management 40:453-475.

aThe geodatabase used for the analyses presented in Andersen et al. (2007) is available through the USGS-developed web application ScienceBase (www .sciencebase.gov/catalog) as the geodatabase "A GIS-based evaluation of Fremont cottonwood stand dynamics in the Southern Rockies LCC." 
Andersen, D.C., AND S.M. Nelson. 2002. Effects of cottonwood leaf beetle Chrysomela scripta (Coleoptera: Chrysomelidae) on survival and growth of Fremont cottonwood (Populus fremontii) in northwest Colorado. American Midland Naturalist 147:189-203.

Beissinger, S.R. 1995. Modeling extinction in periodic environments-Everglades water levels and Snail Kite population viability. Ecological Applications 5:618-631.

Brand, L.A., J.C. Stromberg, D.C. Goodrich, M.D. Dixon, K. Lansey, D. Kang, D.S. Brookshire, and D.J. Cerasale. 2011. Projecting avian response to linked changes in groundwater and riparian floodplain vegetation along a dryland river: a scenario analysis. Ecohydrology 4:130-142.

Brand, L.A., G.C. White, and B.R. Noon. 2008. Factors influencing species richness and community composition of breeding birds in a desert riparian corridor. Condor 110:199-210.

Busing, R.T. 2005. Tree mortality, canopy turnover, and woody detritus in old cove forests of the southern Appalachians. Ecology 86:73-84.

Cooper, D.J., D.C. Andersen, and R.A. Chimner. 2003. Multiple pathways for woody plant establishment on floodplains at local to regional scales. Journal of Ecology 91:182-196.

Cooper, D.J., D.M. Merritt, D.C. Andersen, and R.A. Chimner. 1999. Factors controlling the establishment of Fremont cottonwood seedlings on the upper Green River, USA. Regulated Rivers: Research and Management 15:419-440.

Csilléry, K., M. Seignobosc, V. Lafond, G. Kunstler, AND B. Courbaud. 2013. Estimating long-term tree mortality rate time series by combining data from periodic inventories and harvest reports in a Bayesian state-space model. Forest Ecology and Management 292:64-74.

Dixon, M.D., W.C. Johnson, M.L. ScotT, D.E. Bowen, AND L.A. RabBe. 2012. Dynamics of plains cottonwood (Populus deltoides) forests and historical landscape change along unchannelized segments of the Missouri River, USA. Environmental Management 49:990-1008.

Eckenwalder, J.E. 1977. North American cottonwoods (Populus, Salicaceae) of sections Abaso and Aigeiros. Journal of the Arnold Arboretum 58:193-208.

Edmondson, J., J. Friedman, D. Meko, R. Touchan, J. ScotT, AND A. Edmondson. 2014. Dendroclimatic potential of plains cottonwood (Populus deltoides ssp. monilifera) from the northern Great Plains, USA. Tree-Ring Research 70:21-30. dx.doi.org/ 10.3959/1536-1098-70.1.21

Gitlin, A.R., C.M. Sthultz, M.A. Bowker, S. Stumpf, K.L. Paxton, K. Kennedy, A. Munoz, J.K. Bailey, AND T.G. Whitham. 2006. Mortality gradients within and among dominant plant populations as barometers of ecosystem change during extreme drought. Conservation Biology 20:1477-1486.

Gray, S.T., J.J. LuKas, AND C.A. WoOdhouse. 2011. Millennial-length records of streamflow from three major Upper Colorado River tributaries. Journal of the American Water Resources Association 47: 702-712. dx.doi.org/10.1111/j.1752-1688.2011.00535.x

Hammond, H.E.J., D.W. Langor, and J.R. SPenCE. 2001. Early colonization of Populus wood by saproxylic beetles (Coleoptera). Canadian Journal of Forest Research 31:1175-1183.
Harcombe, P.A. 1987. Tree life-tables. BioScience 37: $557-568$.

Hinchman, V.H., AND K.W. BirKeland. 1995. Age prediction based on stem size for riparian cottonwood stands. Southwestern Naturalist 40:406-409.

Hultine, K.R., S.E. Bush, A.G. West, and J.R. EhLERINGER. 2007. Population structure, physiology and ecohydrological impacts of dioecious riparian tree species of western North America. Oecologia 154:85-93.

Lytle, D.A., AND D.M. MERRITT. 2004. Hydrologic regimes and riparian forests: a structured population model for cottonwood. Ecology 85:2493-2503.

MerritT, D.M., AND D.J. CoOPER. 2000. Riparian vegetation and channel change in response to river regulation: a comparative study of regulated and unregulated streams in the Green River Basin, USA. Regulated Rivers: Research and Management 16:543-564.

Ozolincius, R., V. Miksys, and V. Stakenas. 2005. Growth-independent mortality of Lithuanian forest tree species. Scandinavian Journal of Forest Research 20:153-160. dx.doi.org/10.1080/14004080510042164

Peterken, G.F. 1996. Natural woodlands: ecology and conservation in northern temperate regions. Cambridge University Press.

Richardson, S.J., M.C. Smale, J.M. Hurst, N.B. Fitzgerald, D.A. Peltzer, R.B. Allen, P.J. Bellingham, And P.J. McKelvey. 2009. Large-tree growth and mortality rates in forests of the central North Island, New Zealand. New Zealand Journal of Ecology 33:208-215.

Rood, S.B., D.J. Ball, K.M. Gill, S. Kaluthota, M.G. LetTs, And D.W. Pearce. 2013. Hydrologic linkages between a climate oscillation, river flows, growth, and wood $\Delta^{13} \mathrm{C}$ of male and female cottonwood trees. Plant, Cell and Environment 36:984-993.

Rood, S.B., S. Patiño, K. Coombs, and M.T. Tyree. 2000. Branch sacrifice: cavitation-associated drought adaptation of riparian cottonwoods. Trees 14:248-257.

Rood, S.B., AND M.L. Polzin. 2003. Big old cottonwoods. Canadian Journal of Botany 81:764-767.

Rowland, D.L., and N.C. Johnson. 2001. Sexual demographics of riparian populations of Populus deltoides: can mortality be predicted from a change in reproductive status? Canadian Journal of Botany 79: $702-710$.

Sabo, J.L., R. Sponseller, M. Dixon, K. Gade, T. Harms, J. Heffernan, A. Jani, G. Katz, C. Soykan, J. Watts, AND A. Welter. 2005. Riparian zones increase regional species richness by harboring different, not more, species. Ecology 86:56-62.

SChWARZE, F.W.M.R., J. ENGELS, AND C. Mattheck. 2000. Fungal strategies of wood decay in trees. SpringerVerlag, Berlin. dx.doi.org/10.1007/978-3-642-57302-6

ScoTT, M.L. 2013. Long-term cottonwood forest dynamics along the upper Missouri River, USA. River Research and Applications 29:1016-1029.

ScotT, M.L., G.C. Lines, And G.T. Auble. 2000. Channel incision and patterns of cottonwood stress and mortality along the Mojave River, California. Journal of Arid Environments 44:399-414.

Scott, M.L., P.B. Shafroth, and G.T. Auble. 1999. Responses of riparian cottonwoods to alluvial water table declines. Environmental Management 23: 347-358.

Shafroth, P.B., J.C. Stromberg, and D.T. Patten. 2000. Woody riparian vegetation response to different 
alluvial water table regimes. Western North American Naturalist 60:66-76.

Smith, D.M., AND D.M. Finch. 2014. Use of native and nonnative nest plants by riparian-nesting birds along two streams in New Mexico. River Research and Applications 30:1134-1145.

Stromberg, J.C., D.C. Andersen, And M.L. Scott. 2012. Riparian floodplain wetlands of the arid and semiarid Southwest. Pages 343-356 in D.P. Batzer and A.H. Baldwin, editors, Wetland habitats of North America: ecology and conservation concerns. University of California Press, Berkelely, CA. dx.doi.org/10.1007/ BF03161417

Stromberg, J.C., J. Fry, and D.T. Patten. 1997. Marsh development after large floods in an alluvial, aridland river. Wetlands 17:292-300.

StromberG, J.C., And D.T. Patten. 1992. Mortality and age of black cottonwood stands along diverted and undiverted streams in the eastern Sierra Nevada, California. Madroño 39:205-223.

Stromberg, J.C., B.D. Richter, D.T. Patten, and L.G. WOLDEN. 1993. Response of a Sonoran riparian forest to a 10-year return flood. Great Basin Naturalist $53: 118-130$

Stromberg, J.C., and T.J. Rychener. 2010. Effects of fire on riparian forests along a free-flowing dryland river. Wetlands 30:75-86.

Uowolo, A.L., D. Binkley, and E.C. AdAir. 2005. Plant diversity in riparian forests in northwest Colorado: effects of time and river regulation. Forest Ecology and Management 218:107-114.

Wallace, C.S.A., M.L. Villarkeal, and C. van Riper III. 2013. Influence of monsoon-related riparian phenology on Yellow-billed Cuckoo habitat selection in Arizona. Journal of Biogeography 40:2094-2107.

Williams, C.A., AND D.J. CoOPER. 2005. Mechanisms of riparian cottonwood decline along regulated rivers. Ecosystems 8:382-395.

Received 2.9 September 2014 Accepted 23 March 2015

Appendix on pages 168-169. 
Appendix. Tables A1 and A2 (below) are representations of the Microsoft Excel 2010 spreadsheet used to model graphic variation in the survival process. The actual annual survivorship probability $\left(\mathrm{P}_{\mathrm{S}}\right)$ applied in the model depends drought or other stress is applied. The latter occurs randomly among years with probability $\mathrm{P}(\mathrm{BAD})$. In this illustration, $(=0.00995)$ and $3 \%(=0.028635)$, respectively. $\mathrm{P}(\mathrm{BAD})=0.15$, which translates to poor survivorship, on average, in about with appropriate shifts in formula cell references, for an extent sufficient to assure population extinction. I included 500 example of the results automatically obtained from creating Table A1. Each time a random number is called, all random

TABLE A1. Format and formulas used in an Excel 2010 spreadsheet to stochastically model population decline (see

\begin{tabular}{|c|c|c|c|c|c|}
\hline $\begin{array}{l}\text { Random } \\
\text { number }\end{array}$ & $\begin{array}{c}\operatorname{High} \mathrm{P}_{\mathrm{SH}}(1) \\
\mathrm{SD}=1 \%\end{array}$ & $\begin{array}{l}\text { Random } \\
\text { number }\end{array}$ & $\begin{array}{c}\text { Low } \mathrm{P}_{\mathrm{SL}}(1) \\
\mathrm{SD}=3 \%\end{array}$ & High $\mathrm{P}_{\mathrm{SH}}(2)$ & Low $\mathrm{P}_{\mathrm{SL}}(2)$ \\
\hline$=\mathrm{RAND}()$ & $\begin{aligned}= & \text { NORM.INV } \\
& (\mathrm{A} 3,0.995,0.00995)\end{aligned}$ & $=\mathrm{RAND}()$ & $\begin{aligned}= & \text { NORM.INV } \\
& (\mathrm{C} 3,0.9545,0.028635)\end{aligned}$ & $\begin{array}{c}=\mathrm{IF}(\mathrm{B} 3<= \\
1, \mathrm{~B} 3,1)\end{array}$ & $\begin{aligned}= & \mathrm{IF}(\mathrm{D} 3<= \\
& \mathrm{B} 3, \mathrm{D} 3, \mathrm{~B} 3)\end{aligned}$ \\
\hline$=\mathrm{RAND}()$ & $\begin{aligned}= & \text { NORM.INV } \\
& (\mathrm{A} 4,0.995,0.00995)\end{aligned}$ & $=$ RAND () & $\begin{aligned}= & \text { NORM.INV } \\
& (\mathrm{C} 4,0.9545,0.028635)\end{aligned}$ & $\begin{aligned}= & \operatorname{IF}(\mathrm{B} 4<= \\
& 1, \mathrm{~B} 4,1)\end{aligned}$ & $\begin{aligned}= & \mathrm{IF}(\mathrm{D} 4<= \\
& \mathrm{B} 4, \mathrm{D} 4, \mathrm{~B} 4)\end{aligned}$ \\
\hline$=\mathrm{RAND}()$ & $\begin{aligned}= & \text { NORM.INV } \\
& (\mathrm{A} 5,0.995,0.00995)\end{aligned}$ & $=\mathrm{RAND}()$ & $\begin{aligned}= & \text { NORM.INV } \\
& (\mathrm{C} 5,0.9545,0.028635)\end{aligned}$ & $\begin{aligned}= & \operatorname{IF}(\mathrm{B} 5<= \\
& 1, \mathrm{~B} 5,1)\end{aligned}$ & $\begin{aligned}= & \mathrm{IF}(\mathrm{D} 5<= \\
& \mathrm{B} 5, \mathrm{D} 5, \mathrm{~B} 5)\end{aligned}$ \\
\hline
\end{tabular}

TABLE A2. An example of the numerical results produced by the model presented in Table A1.

\begin{tabular}{lccccc}
\hline $\begin{array}{l}\text { Random } \\
\text { number }\end{array}$ & $\begin{array}{c}\text { High } \mathrm{P}_{\mathrm{SH}}(1) ; \\
\mathrm{SD}=1 \%\end{array}$ & $\begin{array}{c}\text { Random } \\
\text { number }\end{array}$ & $\begin{array}{c}\text { Low } \mathrm{P}_{\mathrm{SL}}(1) ; \\
\mathrm{SD}=3 \%\end{array}$ & High $\mathrm{P}_{\mathrm{SH}}(2)$ & Low $\mathrm{P}_{\mathrm{SL}}(2)$ \\
\hline & & & & & \\
0.665856 & 0.999264 & 0.091196 & 0.916317 & 0.999264 & 0.916317 \\
0.686903 & 0.999847 & 0.495199 & 0.954155 & 0.999847 & 0.954155 \\
0.67391 & 0.999485 & 0.194962 & 0.929881 & 0.999485 & 0.929881 \\
\hline
\end{tabular}


mature Fremont cottonwood population decline in a model incorporating stochastic environmental variation and demoon whether the normal "background" survivorship probability $\left(\mathrm{P}_{\mathrm{SH}}\right)$ is applied or a lower value $\left(\mathrm{P}_{\mathrm{SL}}\right)$ associated with mean $\mathrm{P}_{\mathrm{SH}}=0.995$ year-1 $^{-1}$ and mean $\mathrm{P}_{\mathrm{SL}}=0.9545$ year-1, and standard deviations for those variables are $1 \%$ 1 out of every 7 years. The initial population size is 1000 . Only the first 3 rows of formulas are shown. The rows continue, rows in the models used for the study. Table A1 shows the formulas used in the model, whereas Table A2 shows one numbers change and a new set of output values is obtained.

text for explanation of the model).

\begin{tabular}{|c|c|c|c|c|}
\hline $\begin{array}{l}\text { Random } \\
\text { number }\end{array}$ & $\begin{array}{l}\mathrm{P}(\mathrm{BAD})=0.15 \\
\text { Ps (FINAL) }\end{array}$ & $\begin{array}{l}\text { Random } \\
\text { number }\end{array}$ & Population size $(\mathrm{N})$ & $\begin{array}{l}\text { Year in } \\
\text { model }\end{array}$ \\
\hline$=\mathrm{RAND}()$ & $\begin{aligned}= & \mathrm{IF}(\mathrm{G} 3<=0.15, \mathrm{IF}(\mathrm{F} 3<= \\
& 1, \mathrm{~F} 3,1), \mathrm{IF}(\mathrm{E} 3<=1, \mathrm{E} 3,1))\end{aligned}$ & $=\mathrm{RAND}()$ & $\begin{array}{l}1000 \\
=\mathrm{IF}(\mathrm{H} 3=1, \mathrm{~J} 2, \mathrm{BINOM} . \mathrm{INV} \\
\quad(\text { ROUNDDOWN }(\mathrm{J} 2,0), \mathrm{H} 3, \mathrm{I} 3))\end{array}$ & $\begin{array}{l}0 \\
1\end{array}$ \\
\hline$=\mathrm{RAND}()$ & $\begin{aligned}= & \mathrm{IF}(\mathrm{G} 4<=0.15, \mathrm{IF}(\mathrm{F} 4<= \\
& 1, \mathrm{~F} 4,1), \mathrm{IF}(\mathrm{E} 4<=1, \mathrm{E} 4,1))\end{aligned}$ & $=\operatorname{RAND}()$ & $\begin{aligned}= & \mathrm{IF}(\mathrm{H} 4=1, \mathrm{~J} 3, \mathrm{BINOM} . \mathrm{INV} \\
& (\text { ROUNDDOWN }(\mathrm{J} 3,0), \mathrm{H} 4, \mathrm{I} 4))\end{aligned}$ & 2 \\
\hline$=\operatorname{RAND}()$ & $\begin{aligned}= & \operatorname{IF}(\mathrm{G} 5<=0.15, \mathrm{IF}(\mathrm{F} 5<= \\
& 1, \mathrm{~F} 5,1), \operatorname{IF}(\mathrm{E} 5<=1, \mathrm{E} 5,1))\end{aligned}$ & $=\operatorname{RAND}()$ & $\begin{aligned}= & \mathrm{IF}(\mathrm{H} 5=1, \mathrm{~J} 4, \text { BINOM.INV } \\
& (\text { ROUNDDOWN }(\mathrm{J} 4,0), \mathrm{H} 5, \mathrm{I} 5))\end{aligned}$ & 3 \\
\hline
\end{tabular}

\begin{tabular}{|c|c|c|c|c|}
\hline $\begin{array}{l}\text { Random } \\
\text { number }\end{array}$ & $\begin{array}{l}\mathrm{P}(\mathrm{BAD})=0.15 \\
\text { Ps }(\mathrm{FINAL})\end{array}$ & $\begin{array}{l}\text { Random } \\
\text { number }\end{array}$ & Population size $(\mathrm{N})$ & $\begin{array}{l}\text { Year in } \\
\text { model }\end{array}$ \\
\hline & & & 1000 & 0 \\
\hline 0.14163 & 0.916317 & 0.348748 & 913 & 1 \\
\hline 0.322642 & 0.999847 & 0.765181 & 913 & 2 \\
\hline 0.075287 & 0.929881 & 0.661014 & 852 & 3 \\
\hline
\end{tabular}

